\title{
Application of Neutron Radiography to the Study of Water Behavior in Soil
}

\author{
Tomoko MAKino NAKANISHI, Satoshi MAtsumoto, \\ Hisao KoBAYASHI* and Koichi HANAWA** \\ Department of Agriculture, University of Tokyo \\ 1-1-1, Yayoi, Bunkyo-ku, Tokyo 113, Japan \\ *Institute for Atomic Energy, Rikkyo University \\ 2-5-1, Nagasaka, Yokosuka-shi, Kanagawa-Pref. 240-01, Japan \\ **Tokyo Analytical Applications Lab., Shimadzu Co. \\ 1-63-1, Shibasaki, Chofu-shi, Tokyo 182 \\ Received September 17, 1990
}

\begin{abstract}
Neutron radiography (NR) was applied to study water behavior in soil, non-destructively. Using Toyoura sand as standard, the image of water was correlated well with the water content by chromatogram scanner. The image of water absorbing polymer was also analyzed by NR. As the water content becomes higher, the polymer size and water content comes higher, which was clearly shown by the radiogram. The size of the polymer swelled with water was analyzed by the image scanner and was shown to be related well with the water content. The calibration curves of absorbance with the water content of sand alone and the sand with the polymer indicated that water behavior in the sand could be analyzed quantitatively as well as visually by NR. When the plant was grown in the sand, the image of root and water could be observed in the radiogram. Therefore, the NR was shown to be a useful method for the non-destructive study of water behavior in soil around root.
\end{abstract}

Key Words: neutron radiography, soybean root, water behavior in soil, water absorbing polymer

\section{Introduction}

There are two theoretical approaches to calculate the movement process of water in soil and the water extraction behavior of the plant root. One of the approach is the macroscopic one where the water moves along with the one-dimentional flow toward the root which was regarded as a $\operatorname{sink}^{11}$. However, the quantitative analysis of the flow gradient was difficult, especially around the single root. The other model is based on one single root for the microscopic analysis where the root was treated as a cylindrical sink with the radial flow of water ${ }^{2}$. This microscopic approach had also the difficulty in estimating the quantitative prediction of the water flow. To know the actual movement of water, non-destructive method is needed to perform. For the non-destructive analysis, computer assisted tomography (CAT) to X-ray attenuation measurement was carried out ${ }^{3)}$ and showed that the water uptake decreased with root depth, with the discussion of the discrepancies with the models reported. Since the resolution of CAT image is about $1.5 \mathrm{~mm}$, therefore, the neutron radiography (NR), which resolution is $100 \mu \mathrm{m}$, is expected to provide much finer information of water movement in the soil. The inherent resolution of the NR imaging system has been estimated to be less than 20 $\mu \mathrm{m}^{4}$. For NR method only a few applications have been reported to study the root profiles in the soil ${ }^{5)-7}$. In this work quantitative and non-destructive investigations were undertaken to study the in situ water behavior in the soil, or the soil with water absorbing polymer, while soybean plant is actually growing.

\section{Materials and Methods}

Two types of samples were prepared to make calibration curves for water content in a test sand. First, Toyoura test sand $(105-297 \mu \mathrm{m}$ in mesh size) was packed in two aluminum containers $\left(150 \times 70 \times 3 \mathrm{~mm}^{3}\right)$ devided into 

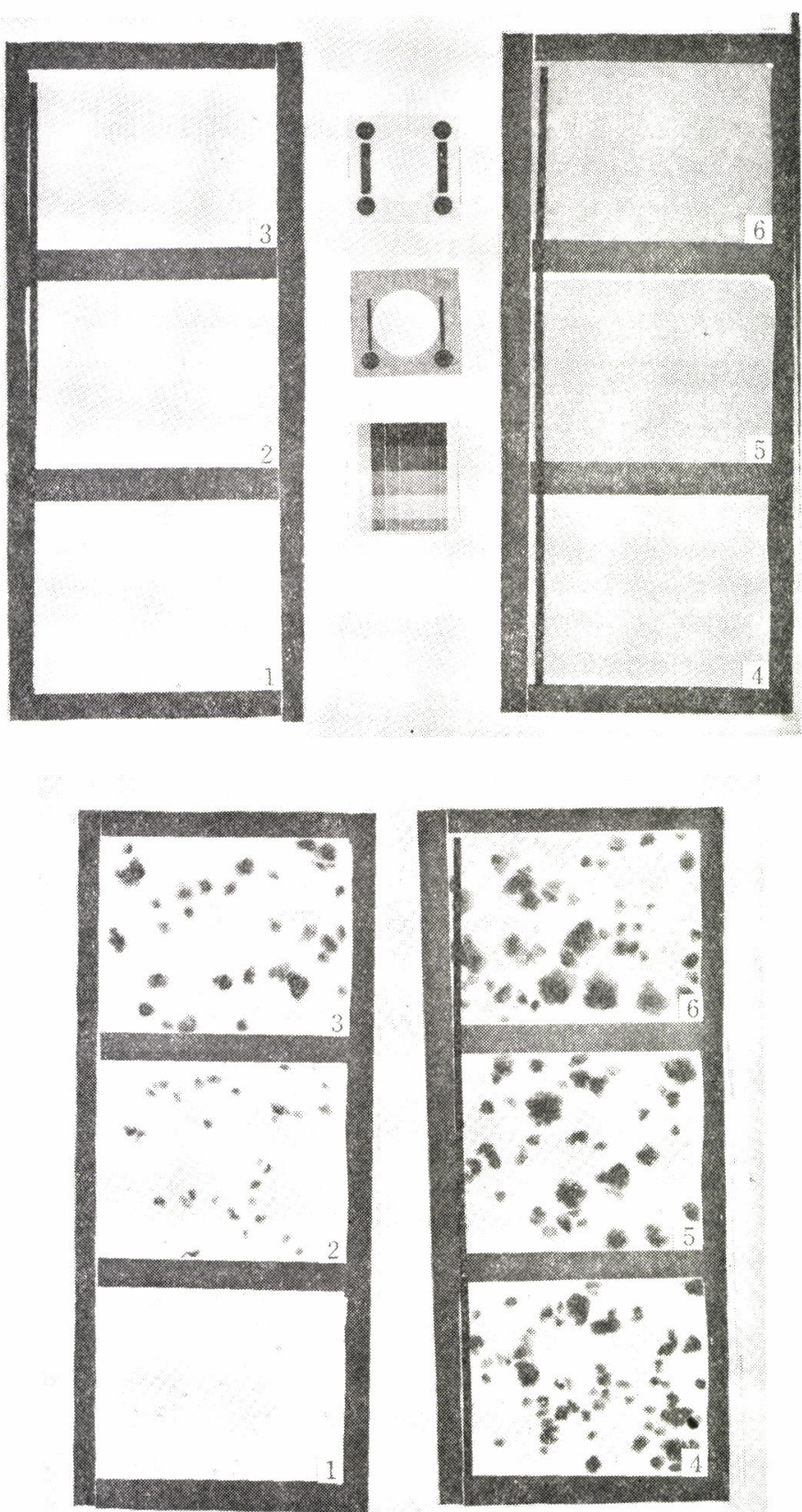

Fig. 1 Image of neutron radiography.

(a) Toyoura sand (standard) was mixed with 0, 5, 10, 15, 20 and $30 \%$ of water which was corresponded and the numbers, 1 to 6 in each frame. (b) The same sand was mixed with $0.3 \%$ of water absorbing polymer and water was added, similarly to (a), frame 1 to 6 . The black bars penetrating in frames 1 to 3 (a) and 1 to 3 and 4 to 6 (b) are the cadmium bars where $100 \%$ of the transmitted neutron beam was cut, and were used to estimate the scattering component. 
three parts individually by an acrylic plates. In each part, $25 \mathrm{~g}$ of the sand with water content of $0,5,10,15,20$ and $30 \%$ in weight, were added and sealed with an aluminum tape to prevent the water reduction during the measurement. Second, the water absorbing polymer (Acryhope, Nippon Shokubai Kagaku Kogyo, Co.) was added to the sand to be $0.3 \%$ in weight and mixed well. The mixture was packed in the aluminum container and the same amount of water as the first sample, 0, 5, 10, 15,20 and $30 \mathrm{wt} \%$, were added in each container to give 6 samples. Three sets of the samples were sealed in one aluminum container with an aluminum tape, similarly. Two of the aluminum containers were placed simultaneously on a vacuum casette in which X-ray film (Kodak SR-5) with an evaporated gadrinium converter of $25 \mu \mathrm{m}$ in the thickness was sealed in a vacuum. The casette with samples was set vertically and exposed to the thermal neutron of $1.3 \times 10^{9} \mathrm{n} / \mathrm{cm}^{2}$ installed in Rikkyo TRIGA-II reactor $^{8)}$.

Soybean, Glycine Max L. Merril, c.v. Kitamusume, was washed with $1 \%$ hypochrolite solution and was germinated at $25^{\circ} \mathrm{C}$. When the root length became about $1 \mathrm{~cm}$ in length, the plant was put on the top of the aluminum container where the sand with $18 \%$ of water was packed. The plant was grown in a phytotron at $25^{\circ} \mathrm{C}$ with sufficient light of 20000 lux, for four days. Then the aluminum container with the plant was exposed to the neutron in the same manner.

After the irradiation, the film was developed and the negative film was reversed to a positive image which enabled to analyze the image. The water content, which was observed as a darker part, was measured by a chromatogram scanner (Shimadzu Co., CS-9000). For the water absorbing polymers, of which images were observed as black spots, the size of each spots was analyzed also by the same scanner with a two dimensional image analyzing system.

\section{Results and Discussion}

Figure 1 shows the NR images of sand with water (a), and sand with polymer and water (b). As is shown in the figure the sand image become darker with the increase of the water content. Numbers 1 to 6 noted in the figure indicate the frames with water content of 0 to $30 \%$, respectively. In the case of sand with polymer the color tone of the polymer also became darker and larger in size with high amount of the water. That means, the polymer absorbed much water than the sand, which was indicated much darker color of the polymer. Therefore, less water is remained in the sand as the water content becomes higher.

To determine the water content, the density of the photograph was measured by the chromatogram scanner. The result is shown in Fig. 2. The water content was shown to be logarithmically correlated to the darkness in the picture, i.e. the total absorbance of the

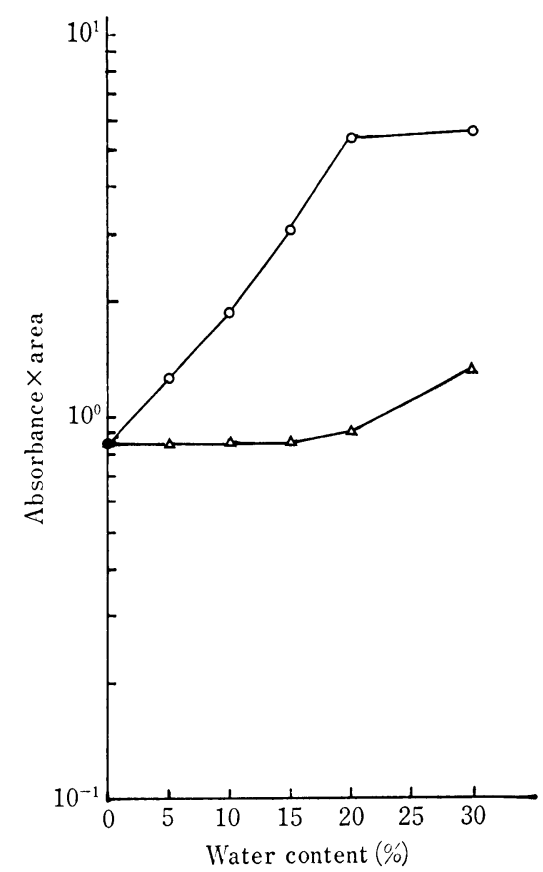

Fig. 2 Water content of the sand in Fig. 1. The darkness in the figure, i.e. the water content was measured by the chromatogram scanner. The cadmium bars which was transparent in the $\mathrm{X}$ ray film, opposit to the picture, was set as 0 in the absorbance. Thus, scattering components of neutrons were corrected automatically. $\bigcirc$ is the case of the sand alone (a) and $\Delta$ is that of the sand when the polymer was mixed. The frames were linearly scanned from top to the bottom and the value of the (absorbance) $\times$ (sand area) was plotted. 

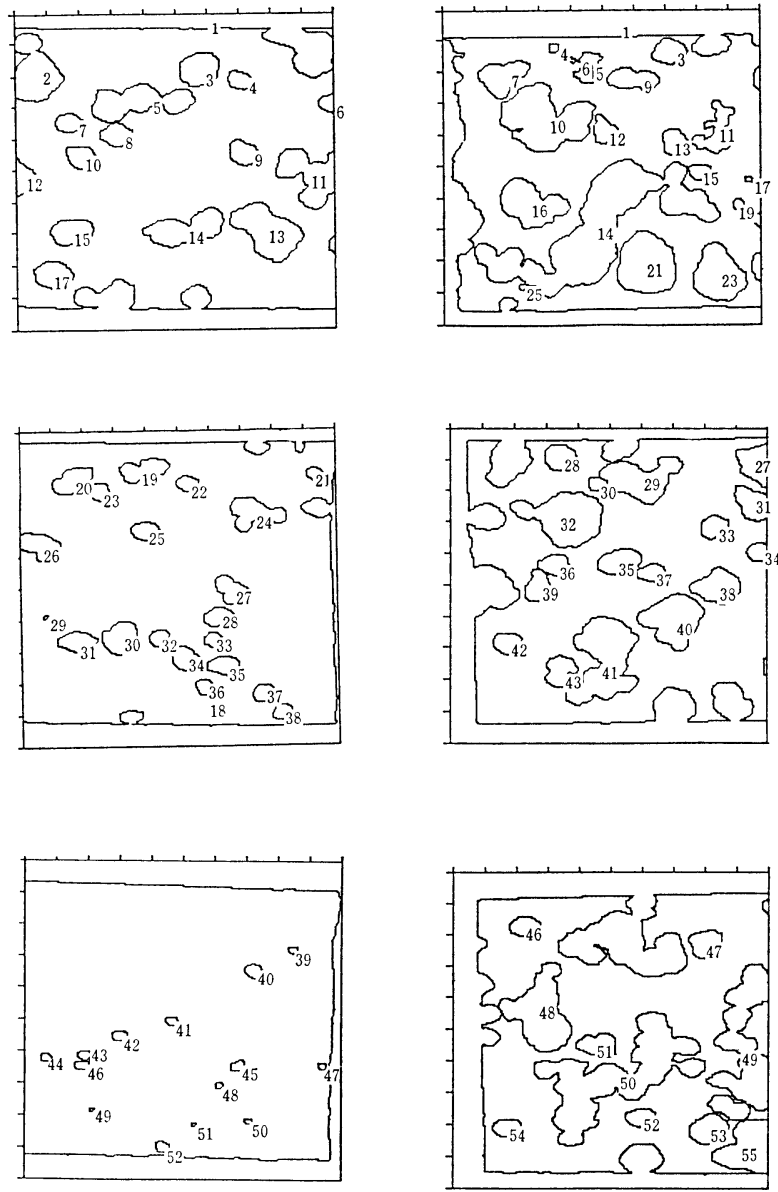

Fig. 3 The image of the polymer in Fig. 1 (b) was analyzed by the chromatogram scanner with image analyzing system.

The image was cut at the absorbance of 0.48 when the absorbance at the cadmium bar was set as 0 .

area measured. The images of cadmium bars with the most transparent part in the film, which was shown as the darkest part in the picture, was set as zero in the absorbance. Thus the scattering component of neutrons were automatically corrected in comparison with the cadmium image ${ }^{9)}$. As is shown in the figure, the water content in the sand became much lower than the sand alone when the polymer was added. For example, when $30 \%$ of the water was added, the water content of the sand was lowered to be about $13 \%$.

The polymer size along with the different water content was analyzed two dimentionally by the same chromatogram scanner. The image of the polymers obtained by the chromatogram scanner is shown in Fig. 3. The absorbance of the whole area was scanned and at the absorbance of 0.48 , every frame was cut, where the most transparent part of cadmium bar was set as zero in absorbance. The total area of the polymers appeared in each frame of Fig. 3 was summed up and was proved to be correlated well with the water content (Fig. 4).

When the soybean was grown in the aluminum container the root and the water profile in the container was investigated by the NR (Fig. 5). Interestingly, since the water content in the 
root was higher than the sand, the root pattern was clearly indicated in the figure. The amount of the water in the sand absorbed by the root was higher around the larger root, i.e. at the upper part, which was in good agreement with the observation by CAT method ${ }^{3}$. The chro-

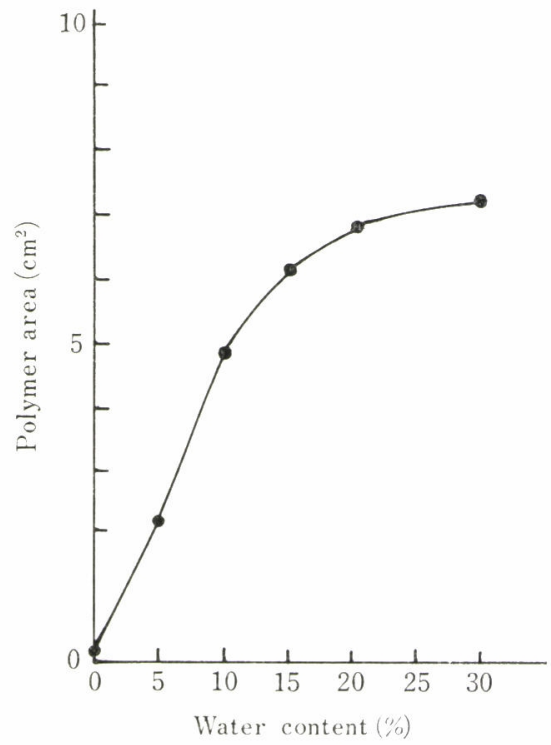

Fig. 4 The area of the polymer image outlined in the Fig. 3 was summed up by the analyzer and plotted against the water content of the frame. matogram across the root as indicated in a bar is also shown in the figure. The peak in the chromatogram indicates the root.

The purpose of this study was to investigate the applicability of NR method to soil study. As is shown in the Figs. 1 and 5, the water content in the sand was quantitatively measured by this method. For the determination of the water content, using the calibration curve shown in Fig. 2, we could calculate the water content in the sample. To investigate the root or water content of soil part of the sample had to be taken out for the analysis. However, by the NR, non-destructive analysis was shown to be the promising method for both root study and water behavior in the soil. Another aim of this study was whether this method could be applied for the usefulness of the water absorbing polymer using the image analyzer. Polymer of this kind has been reported to improve the quality of the sand by retaining the water which enables the growth of plants. Using this method, the role of the polymers in the sand will be clarified both visually and quantitatively.

\section{References}

1) Hillel, D., Talpaz, H. and van Kenlen, H.: Soil Sci., 121, 242-255 (1976)

2) Hillel, D., van Beek, C. and Talpaz, H.:
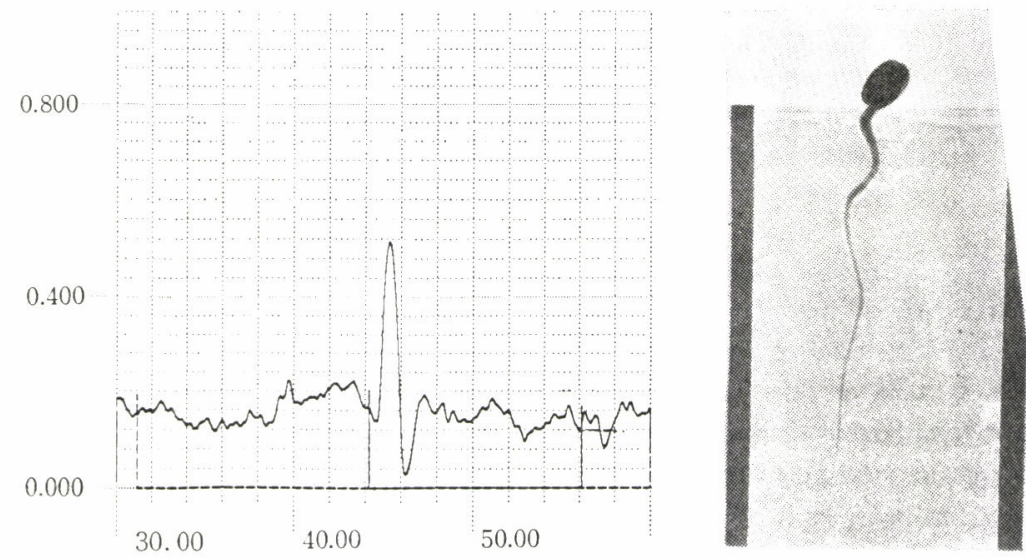

Fig. 5 The neutron chromatogram of the soybean grown in the container for four days.

The white part around the root indicates water deficient part. The chromatogram shows when the photograph was scanned along with the bar indicated in the figure. The high peak in chromatogram is the root and the low peak corresponds to the water deficient part adjacent to the root. 
ibid., 120, 385-399 (1975)

3 ) Hainsworth, J.M. and Aylmore, L.A.G.: Soil Sci. Am. J., 50, 841-848 (1986)

4) Kobayashi, H., Ikeda, Y., Ohkubo, K. and Wakao, H.: "Neutron Radiography3”, pp. 893, Kluwer Academics (1990)

$5)$ Couchat, P., Moutonnet, P., Houelle, M. and Picard, D.: Agron. J., 72, 321-324 (1980)
6) Willatt, S.T., Struss, R.G. and Taylor, H.M.: ibid., 70, 581-586 (1978)

7) Willatt, S.T. and Struss, R.G.: Ann. Bot., 43, 415-422 Figure Captions (1979)

8) Kobayashi, H.: Proc. 1st Asian Symp. on Research Readors, (Tokyo, Jan. 1986) pp. 360

9) Kobayashi, H.: "Neutron Radiography3”, pp. 893, Kluwer Academics (1990)

要旨

\title{
中性子ラジオグラフィを用いた土䁃中における水分動態の研究
}

\author{
中西友子, 松本 聡, 小林久夫*, 花輪浩一** \\ 東京大学農学部 113 東京都文京区弥生 1-1-1 \\ *立教大学原子力研究所 240-01 横須賀市長坂 2-5-1 \\ **島津製作所東京分析センター 182 調布市柴崎 1-63-1
}

\begin{abstract}
中性子ラジオグラフィ（NR）により，土壌中の水分動態を非破壊法で測定した。試料は，豊浦の 標準砂，標準砂に土境改良用吸水性ポリマーを添加した砂および植物育成中の標準砂を用いた。豊 浦砂中の水分量は，NR 像の黒化度により定量されることが示された。土嚊中の吸水性ポリマーの 粒子の大きさは，水分を吸収することにより増大するが，ポリマー添加土壌のNR像により，土境中 の水分のポリマーヘの移行状態が解明された。また，粒子のNR 像を画像解析することにより水分 量が定量されることが示された。育成中の大豆の根の近傍の水分動態もNRにより解析された。
\end{abstract}

